\title{
TEMPO E MEMÓRIA DO ANTIGO MATO GROSSO: A (RE)SIGNIFICAÇÃO DO CRISTIANISMO OCIDENTAL NA COSMOLOGIA TERENA.
}

\author{
Noêmia dos Santos Pereira Moura \\ Doutora em Ciências Sociais pela Universidade Estadual de Campinas. Docente no \\ Curso de Ciências Sociais e no Programa de Pós-Graduação em Antropologia da \\ Faculdade de Ciências Humanas na Universidade Federal da Grande Dourados. \\ noemiamoura@ufgd.edu.br
}

\begin{abstract}
Rosalvo Ivarra Ortiz
Metrando em Antropologia Sociocultural pelo Programa de Pós-Graduação em Antropologia da Faculdade de Ciências Humanas na Universidade Federal da Grande Dourados. Bolsista FUNDECT. rosalvortiz@hotmail.com
\end{abstract}

resumo: o presente ensaio tem como intento evidenciar o processo de institucionalização do cristianismo no Estado de Mato Grosso do Sul e como deu- se a "metamorfose" dos Terenas, que resistiram por muito tempo ao cerco da sociedade nacional e regional. Na segunda metade do século XIX, antes da Guerra do Paraguai (1964-1970), muitos dessa etnia foram aldeados pelos missionários católicos e no início do século $X X$ muitos outros converteram- se ao protestantismo. Contudo, como o processo de institucionalização do catolicismo e do protestantismo foi lentamente processado ainda no antigo Mato Grosso, os indígenas foram negociando espaços para as novas crenças e ao mesmo, sem perder de vista os seus costumes, hábitos, ou seja, continuaram praticando o xamanismo e suas práticas cosmológicas.

Palauras-chave: Povo Terena, Conversão Cristã, Xamanismo. abstract: The present essay attempts to highlight the process of institutionalization of Christianity in the State of Mato Grosso do Sul and how the Terenas' "metamorphosis" took place, which for a long time resisted the siege of national and regional society. In the second half of the nineteenth century, before the Paraguayan War (1964-1970), many of these ethnic groups were marched by Catholic missionaries, and in the early 20th century many others converted to Protestantism. However, as the process of institutionalization of Catholicism and Protestantism was slowly processed in ancient Mato Grosso, the Indians were negotiating spaces for new beliefs and the same, without losing sight of their customs, habits, that is, they continued practicing the shamanism and its cosmological practices.

Key-words: Terena People, Christian Conversion, Shamanism. 
Brasil foi um país hegemonicamente católico até a segunda metade do século XIX, quando o protestantismo inseriu- se no campo religioso brasileiro. A partir desse momento, os agentes religiosos iniciaram uma disputa não só pelos espaços religiosos, mas também nas diferentes maneiras de desempenhar o papel religioso. As duas vertentes do Cristianismo procuraram modelar a religião, bem como suas práticas para conquistar fiéis ou assegurar aqueles consagrados na religião oficial. Daí por diante o campo religioso brasileiro foi cada vez se ampliando mais e as disputas cada vez ficando mais acirradas

No Mato Grosso, região de fronteira brasileira com países tais como o Paraguai e a Bolívia, o Catolicismo e o Protestantismo reproduziram as disputas enfrentadas em nível nacional, porém as difículdades para desenvolver 0 Cristianismo eram enormes. Castilho $0^{1}$ desnudando o cenário político, religioso e cultural da Igreja Católica no Estado, corroborou que, somente em 1910, Corumbá tornou-se Díocese, desmembrando-se de Cuiabá, juntamente com São Luiz de Cáceres. Esta Diocese cobria uma área equivalente ao tamanho do atual Estado de Mato Grosso do Sul e seu quadro religioso era ínfimo. Somente em 1957, foi criada a Diocese de Campo Grande, cujo território foi desmembrado da Diocese de Corumbá. Todavia, as dificuldades de deslocamento e a falta de recursos e quadros religiosos continuaram dificultando o trabalho.

Essa situação, entre outras, levou a Igreja Católica a impulsionar a formação de leigos para assumir algumas atividades religiosas. Através de sua obra Marin² descreveu a situação na qual se encontrava a Diocese de Corumbá nas primeiras quatro décadas do século passado, salientando o objetivo da Santa Sé em romanizar o Sul de Mato Grosso. Devido a sua extensão e o reduzido quadro de religiosos a

${ }^{1}$ CASTILHO, Maria Augusta de. O cenário político, religioso e cultural da Igreja Particular de Campo Grande na administração de Dom Antônio Barbosa. IN: MARIN, Jérri Roberto (org.). Religiões, religiosidades e diferenças culturais. Campo Grande: Ed. UCDB, 2005, p. 190.

2 MARIN, Jérri Roberto. A romanização numa região fronteiriça: o caso da diocese de Santa Cruz de Corumbá. In: VIII Encontro Estadual de História:experiências e desafios. Caderno de Programação e Resumos. Florianópolis: Nova Prova, 2000. v. 1. p. 65. 
tarefa era desafiadora. Alguns padres menos zelosos, segundo o autor, abandonaram - sacerdócio e mudaram de religião. A principal meta da instituição era homogeneizar as práticas religiosas, enquadrando-as segundo o modelo europeu sacramental e clerical. "As práticas do catolicismo popular consideradas pelos agentes romanizadores como "ignorância" religiosa a serem extirpadas, eram freqüentes, agravadas pelo indiferentismo religioso predominante"3.

Iniciava-se o trabalho de institucionalização do catolicismo na região e a consequente capilaridade das atividades religiosas, que até então eram esparsas e descontinuadas. De acordo com as conclusões do historiador Jerri Marin, a Romanização da Igreja Católica nesta região, só começou a ser concretamente percebida a partir de 1940

As paróquias não tinham vida espiritual. As igrejas eram, em sua maioria, taperas, e houve casos de criação de várias paróquias, sem ter, ao menos, uma capela na sede da mesma. Os fiéis não sabiam se comportar adequadamente na Igreja, os sacramentos não eram praticados. $\bigcirc$ casamento civil sem o religioso era comum e poucos leigos preocupavam-se em realizá-lo. Na região sul-mato-grossense, a autoridade dos padres não era aceita pelos leigos, e estes não os reconheciam como condutores como líderes autênticos. Esta autonomia não era aceita pelo modelo de catolicismo romanizado, que procurava destituir os leigos de toda e qualquer autonomia submetendo-os à esfera clerical. Agravava a situação a concorrência que a Igreja Católica enfrentava na região do protestantismo do espiritismo, do candomblé, da umbanda e das práticas de feitiçaria que encontraram todos, na região, inúmeros adeptos. ${ }^{4}$

A intenção dos religiosos era abranger todos os habitantes da região. No tocante aos povos indígenas que habitavam o sul de Mato Grosso, dentre eles os Terena, várias foram às tentativas dos missionários católicos de convertê-los, a partir da política de aldeamentos religiosos. Ainda no Mato Grosso Província os Capuchinhos italianos conseguiram estabelecer na segunda metade do século XIX o aldeamento batizado como a Aldea Normal de Miranda. Os registros desse aldeamento se encontram nos livros da Directoria Geral dos Índios, muitos dos quais se encontram hoje digitalizados.

\footnotetext{
${ }^{3}$ MARIN, J. A Romanização da Igreja Católica no Sul de Mato Grosso (1910-1940). Associação Brasileira de História das Religiões. Papers do I Simpósio da ABHR. Recife. Disponível em: <http://bmgil.tripod.com/papers1.htm>. Acessado em 01 de agosto de 2008. >, p. 4.

${ }^{4}$ Idem.
} 
A Aldea Normal de Miranda, fundada em Abril de 1860, agrupava em torno de 2.500 índios das etnias Terena, Laiana e Guachi. Foram descritos pelos administradores como mansos, pacíficos, hospitaleiros e agricultores. Eram aptos ao desenvolvimento intelectual e moral e, portanto, poderiam ser aproveitados nas mais variadas ocupações industriais. Produziam gêneros alimentícios: milho, arroz, feijão, cana e mandioca, cujos excedentes comercializam. Segundo os missionários, os indígenas utilizavam em suas roças ferramentas como foice, enxada, machado e arado que recebiam como presentes da Presidência da Província. Os brindes eram intermediados pela Directoria Geral dos Índios.

Além do trabalho interno, os indígenas eram recrutados para desenvolver atividades externas nas fazendas circunvizinhas, prática que até hoje é recorrente entre os Terena de Reservas e os fazendeiros sul-mato-grossenses. As relações trabalhistas eram mediadas pelo Capitão indígena e pelo Director da Aldeia (um missionário), que ajustavam a mão-de-obra dos aldeados a quaisquer serviços. Ocupavam-se da criação de gado vacum e cavalar, bem como de extração de madeira, confecção de cercas para impedir o gado de se alongar muito, entre outros pequenos serviços.

As mulheres, obedecendo a uma divisão interna de trabalho estabelecida nos aldeamentos, fiavam e teciam o algodão e a lã com os quais faziam redes, cintas e suspensórios muito apreciados. Provavelmente, na convivência com outras mulheres das etnias kinikinao, Guaná e Layana iam se apropriando de outros saberes artesanais. E continuavam a exercer os papéis sociais intrínsecos as suas culturas.

Os indígenas da Aldea foram treinados para desenvolver outras atividades econômicas. Para isso, foram construídos, por homens nacionais contratados, fornos de cal, de telha e de tijolo. Os empreendimentos internos ao aldeamento eram levantados por esses trabalhadores indígenas. Foi instalada, dessa forma, uma escola de Primeiras Letras e uma Capela nas quais os missionários ensinavam os aldeados a ler, escrever e rezar. Os aldeados, principalmente os homens, entendiam e falavam o português o que muito facilitava a comunicação com seus superiores imediatos o Missionário e o Diretor de Aldeia (o que está presente nos Relatórios da Díretoria Geral dos Índios à Presidência da Província dos anos de $1858^{5}$ e $1862^{6}$ ).

\footnotetext{
${ }^{5}$ Relatório de João Baptista D’Oliveira, Director Geral dos Índios, ao Presidente de Província Raimundo Lamare. Cuiabá, 31.12.1858, p. 92-99. Localiza-se no Livro Copiador das Cartas expedidas pela diretoria Geral dos Índios-Província de Mato Grosso (1848-1860). Arquivo Público do Est. de Mato Grosso. (Mat. microfilmado).

${ }^{6}$ Relatório do Director dos Índios João Baptista D’Oliveira ao Presidente da Província Conselheiro Herculano Ferreira Penna. Cuiabá, 28.04.1862. Localiza-se no Livro Copiador das Cartas expedidas pela diretoria Geral dos Índios-Província de Mato Grosso (1848-1860). Arquivo Público do Est. de Mato Grosso. (Mat. microfilmado).
} 
Esse é um panorama geral do cotidiano do aldeamento. Aos poucos os aldeados iam se apropriando das novas relações sociais, políticas, econômicas, culturais e religiosas. Aprendiam a ler, a fazer tijolos, a levantar prédios, a lidar com o gado e a realizar outras atividades necessárias. A civilização dava-se por meio das relações de trabalho e dos ensinamentos religiosos na escola e no convívio cotidiano dos índios com os missionários, o diretor de aldeia, os fazendeiros e os demais grupos indígenas com quem passavam a se relacionar

Os aldeamentos que eram instrumentos governamentais para civilizar e catequizar os povos indígenas mansos foram dirigidos como verdadeiras empresas. Os índios eram ajustados pelos regionais não indígenas, principalmente por fazendeiros e agricultores para desenvolverem várias atividades remuneradas. De acordo com Cunha?, podemos dizer que os mesmos serviam de infraestrutura, fonte de abastecimento e reserva de mão-de-obra para os empreendimentos regionais.

De acordo com os estudos da historiadora $\operatorname{Vargas}^{8}$ referentes à segunda metade do século XIX, com base na análise do texto de Francis Castelnau. os Terena que habitavam a região sul do Mato Grosso detinham desde antes da experiência da Aldea de Miranda conhecimentos tais como cultivar e fiar o algodão, desenvolver a agricultura variada em pequenos roçados, domesticar e lidar com cavalos e gado. $\bigcirc$ novo então desde 1845, quando Castelnau os encontrou aldeados na região de Miranda-MT, pelo que conclui, foram os ensinamentos religiosos, a leitura e a escrita e as relações trabalhistas mais estreitas e recorrentes com os regionais, dos quais sempre mantiveram certa distância. Por outro lado, a concentração de vários grupos indígenas num mesmo local, planejada pela Província e realizada pelos religiosos tinha outro objetivo.

Ainda, segundo a análise de Vargas, os aldeamentos e depois as reservas federais, foram instrumentos de desterritorialização e reterritorialização, através dos quais as terras indígenas foram liberadas para a exploração dos não indígenas, enquanto terras devolutas.

\footnotetext{
${ }^{7}$ CUNHA, M. C. (org.) História dos índios no Brasil. $2^{\text {a }}$ ed. São Paulo: Companhia das Letras: Secretaria Municipal de Cultura: FAPESP, 1998, p. 144.

8 VARGAS, Vera Lúcia Ferreira. A construção do território Terena (1870-1966): uma sociedade entre a imposição e a opção. Dissertação (Mestrado em História), Programa de Pós-Graduação em História, Universidade Federal do Mato Grosso do Sul, Dourados, 2003, p. 51.

${ }^{9}$ CASTELNAU, Francis. Expedição às Regiões Centrais da América do Sul (1845). Trad. Olivério $M$. de Oliveira Pinto. Tomo II. São Paulo: Ed. Nacional, 1949, p. 301-302. Apud VARGAS, Vera Lúcia Ferreira. A construção do território Terena (1870-1966). Op. Cit., p. 51.
} 
Extensas áreas territoriais fícavam "vazias" e os novos lugares de índios seriam ambientes adequados para a miscigenação e a interação cultural. Todavia, a autora pondera que esses espaços podiam ser lidos pela ótica de afírmação identitária étnica favorável aos povos indígenas.

Apesar da experiência cristã católica em Aldea de Miranda ter passado por muitos contratempos - dentre eles a suspensão pelo presidente da Província da verba para a rubrica catequese e civilização e a eclosão da Guerra contra o Paraguai (1864-70), acreditamos que este contato tenha contribuído para a apropriação e autodenominação da identidade de "cristão" pelos indígenas desta etnia. Nesse período, segundo Sganzerla ${ }^{10}$, alguns indígenas aprenderam a ler, escrever e desenvolver vários trabalhos manuais. Esses novos instrumentos potencializaram essa etnia para lutar pelas suas antigas aldeias ${ }^{11}$. Todas as visitas realizadas pelos líderes Terena ao governo da Província e do Império eram mediadas por petições escritas. ${ }^{12}$

Olhando através das lentes da antropóloga e historiadora Maria Regina Celestino de Almeida ${ }^{13}$, destaco que se por um lado os indígenas eram submetidos a uma convivência multiétnica, a exploração de sua mão de obra e a extorsão de suas terras, por outro, organizavam-se para configurar uma categoria hierarquicamente superior àquela dos índios escravos e arredios. Ou seja, os Terena aldeados em terras que conquistaram tinham condições de organização que anteriormente não era possível desfrutar. Portanto,

Apesar das perdas, a condição de aldeados lhes dava alguns privilégios em relação aos que ocupavam posição inferior na escala social. Tinham direito a terra, embora uma terra bem mais reduzida que a sua original, tinham direito a não se tornarem escravos, embora fossem obrigados ao trabalho compulsório, e a se tornarem súditos cristãos, embora tivessem que se batizar e, em princípio, abdicar de suas crenças e costumes. Às lideranças tínham direito a títulos, cargos, salários e prestígio social. Dentro

10 SGANZERLA, Frei Alfredo. A História de Frei Mariano de Bagnaia: o missionário do pantanal. Campo Grande-MS: FUCMT, 1992.

11 SGANZERLA, Frei Alfredo. A História de Frei Mariano de Bagnaia: o missionário do pantanal. Campo Grande-MS: FUCMT, 1992. Apud MOURA, N, S, P. UNIEDAS: o símbolo da apropriação do protestantismo norte-americano pelos Terena crentes (1972-1993). Dissertação (Mestrado em História). Programa de PósGraduação em História, Universidade Federal de Mato Grosso do Sul, Dourados, 2001.

12 VARGAS, Vera Lúcia Ferreira. A construção do território Terena. Op. cit.

${ }^{13}$ ALMEIDA, Maria Regina Celestino de. Metamorfoses Indígenas: Identidade e cultura nas aldeias coloniais do Rio de Janeiro. Rio de Janeiro: Arquivo Nacional. Prêmio Arquivo Nacional de Pesquisa, 2003. 
dessas condições limitadas, restritas e, sem dúvida, opressivas, os índios aldeados encontraram possibilidades de agir para fazer valer esse mínimo de direitos que a lei, apesar de oscilante, lhes garantia, e fizeram isso até o século XIX, conforme os vários exemplos.."14

Os Terena e, principalmente as lideranças da luta pela terra, devem ter concluído que civilização e cristianização eram indissociáveís e, portanto, havia a necessidade de serem reconhecidos enquanto civílizados e para isso cederam ao Cristianismo. A aceitação da identidade cristã foi uma tática de aproximação e reconhecimento dos indígenas pelos regionais. Aponto a posição Terena em aceitar a política de aldeamento e do cristianismo católico, no fínal do século XIX, como uma possibilidade de inversão e subversão da ordem pelos mais fracos. Esta tática será utilizada também na reorganização dos espaços nas reservas, quando vão aos poucos repartindo a terra continua em aldeias. ${ }^{15}$

Após o trabalho missionário desenvolvido pelos Capuchinhos italianos, com destaque ao aldeamento dirigido pelo Frei Mariano de Bagnaia (1886), irrompeu o conflito platino, que envolveu indiretamente os povos indígenas que habitavam a região sul de Mato Grosso, uma das mais afetada. Entre a Guerra contra o Paraguaí (1864-70) e a proclamação da República (1890) os missionários católicos Salesianos substituíram os Capuchinhos. Faz-se necessário recordar que em 1886 restava somente Frei Bagnaia, pois os demais teriam se transferido, morrido ou retornado para as suas origens. Os Salesianos vieram para Mato Grosso a convite do Presidente da Província. A Ordem chegou em 1884 e iniciou suas atividades com os povos indígenas em 1895, conforme os registros da Missão Salesiana de Mato Grosso ${ }^{16}$. Na Missão com os índios, seu alvo principal foram os Bororo-Coroado, que foram reduzidos e pacificados.

trabalho junto aos Bororo foi requerido em caráter de urgência pela Presidência, uma vez que a etnia se constituía em obstáculo ao progresso da Província. $\bigcirc$ Padre Malan, responsável pela Ordem Salesiana na Diocese de Cuiabá voltou sua atenção para os povos recém-pacificados, e deixou os integrados fora do alcance da ação missionária. Os indígenas tidos como catequizados, portanto, integrados, foram englobados em situações de atendimento geral, como no caso da Missão de 1898, destacada abaixo, sob a responsabilidade do Padre Solari.

${ }^{14}$ Idem, ibidem, p. 263-264.

15 CERTEAU, Michel de. A Invenção do Cotidiano: artes de fazer. Petrópolis: Vozes, 1994.

${ }^{16}$ Histórico disponível na Internet: http://www.msmt.org.br/historia.php, no site da Missão Salesiana de MT [s/d de acesso]. 
Mesmo assim, os Salesianos fundaram em Mato Grosso três colônias: Sagrado Coração, em 1902. Imaculada Conceição e São José, em 1905..17 A Colônia Imaculada Conceição situada no município de Aquidauana foi fundada em 1892 e, naquele contexto, se localizava no Estado do Mato Grosso. Na década de 1970 com a divisão do Estado Aquidauana passou a pertencer ao novo Estado de Mato Grosso do Sul (1975).

Em toda a sua viagem, que o leva a Corumbá, Ladário, Miranda, Aquidauana, Campo Grande, Maracaju, Nioaque, etc. [Pe. Solari] só encontra um sacerdote, em Corumbá. Este velho, achacadiço e original, tinha ornado as paredes da sacristia da matriz com o retrato de Garibaldi. Não se preocupava com a evangelização do povo e bem pouco com a sua sacramentalização. Até recusou ouvir a confíssão do P. Solari1. ${ }^{18}$

reduzido número de religiosos fazia com que os próprios missionários se desvirtuassem dos cânones católicos e mergulhassem na cultura regional, que se dedicava quando muito às práticas religiosas populares, tais como o batismo em casa, o casamento só no religioso, entre outras. A narrativa de Duroure retrata a composição da extensa Diocese de Cuiabá:

Mato Grosso formava uma única díocese - a de Cuiabá - com 16 paróquias canonicamente erectas e somente uma meia dúzía de sacerdotes diocesanos - na sua maioria impedidos pela idade avançada ou pelas enfermidades - de evangelizar seu povo. (.) 17 de Abril de 1898. (..) Dom Carlos Luís D’Amour solta uma Pastoral para anunciar a ida de padres Salesianos em Missão extraordinária ao sul de Mato Grosso. (..) A 12 de Julho de 1898, embarca o padre Solari, acolitado de dois exalunos, decididos a partilhar as fadigas da longa e difícil viagem. (..) Miranda, em 1898, contava mil habitantes. Dista da capital do estado: 515 km. No território da paróquia vegetam os índios Terenos, já civilizados, de bom gênio, que cultivam a terra. Uma delegação deles visita o padre, oferecendo-lhe batatas e bananas. (..) Viaja o dia todo em companhia

17 VASCONCELOS, Cláudio Alves de. A Questão Indígena na Província de Mato Grosso: conflito, trama e continuidade. Campo Grande: Editora UFMS, 1999, p. 122-123.

${ }^{18}$ DUROURE, João Baptista. Dom Bosco em Mato Grosso. Campo Grande: UCDB, 1977, p. 78. 
dos catequistas e do Senhor Anastácio Vincenzo. (..) De manhã, o padre celebra a Santa Missa, batiza sete crianças e assiste a um casamento de índios terenos. De noite, às 20:00 horas, ensopados, famintos, sem força, fazem uma triste entrada em Aquidauana. ${ }^{19}$

Conforme pude deduzir, a partir das informações da obra de Duroure, a enorme Diocese de Cuiabá tinha um número diminuto de missionários e se encontrava praticamente desprovida de quaisquer atendimentos religiosos às paróquias. Não somente os povos indígenas, mas também os regionais viviam fora das regras de conduta da Igreja. Eram ao todo 16 paróquias $^{20}$, as quais se localizavam distantes umas das outras. $O$ acesso a estas era difícil, segundo o relato do autor que destaca os escritos dos missionários.

O índio Terena, segundo o relato do autor destacado acima, vivia em bandos que "vegetavam no território da paróquia de Miranda". No entanto, reconheceram a Missão e mais, ofertaram aos missionários alguns dos produtos de suas colheitas. $\bigcirc$ verbo vegetar não corresponde às pessoas que tem o que doar. Para doar elas têm que primeiro produzir. $\bigcirc$ reconhecimento Terena da Missão, segundo minha interpretação, salientava uma relação anterior com a Igreja Católica, remetida, possivelmente, a uma memória ancestral da atividade de catequese desenvolvida por Frei Mariano de Bagnaia (1859-64). A oferenda, um ritual da Santa Missa, representava um prévio contato com os rituais do catolicismo, além de manifestarse como um sinal de solidariedade e fraternidade para com os enviados pela Díocese. Estas ações caracterizavam os Terena enquanto catequizados e, portanto, civilizados para os regionais e para os missionários.

Vera Vargas afirma em sua dissertação de mestrado que os Terena permaneceram nas fazendas, vilas e povoados até o início do século XX, quando foram levados para as Reservas Indígenas criadas a partir de 1905 e reconhecidas posteriormente pelo Serviço de Proteção ao Índio (SPI), após sua criação em 1910. Entretanto, nem todas as famílias e indivíduos Terena migraram para as Reservas, pois muitos preferiram ficar onde estavam.

19 Idem, ibidem, p. 153-166.

${ }^{20}$ Cf. Sganzerla, 1992.Apud Moura, 2013, 2009.

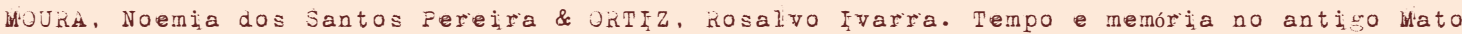

Grosso: a (re)sisnificacão do cristianismo ocidental na cosmolousia Terena.

albuquerque: revista de nistória. val. 9, nolz.jul.-dez. de $2017, \mathrm{p} \cdot 33-47$.
} 
Nas reservas, os indígenas passaram do atendimento dos Salesianos para os Redentoristas. $\bigcirc$ relato abaixo enfatiza a chegada dos primeiros Redentoristas à Aquidauana em 1930 e os primeiros estudos realizados por estes sobre a cidade. $\mathrm{Na}$ citação, o Redentorista Eskerre está referindo-se ao final do século XIX, quando foi fundada a primeira Capela do município de Aquidauana-MT (1982), conforme lhes relataram os Salesianos.

Naquele tempo a Via Férrea Noroeste ainda não tinha aberto caminho com seus trilhos dentro do Estado do Mato Grosso, tanto que todos suplementos tinham que vir pela água assim uma viagem absorvia três meses para ser feita. Isto significa ir por água do Rio de Janeiro à Buenos Aires, pois subia o Rio Paraguai, descia - Rio Miranda e entrava no Rio Áquidauana. Não surpreendente - Oeste era uma terra tranqüila naquele tempo os núcleos da cidade cresciam nos arredores das margens do Rio, e em 1898 o alicerce de uma Capela dedicada a Nossa Senhora da Imaculada Conceição foi assentado, apenas a alguns metros do porto por um Sacerdote residente em Nioaque (que hoje é uma afastada capela enviada por Aquidauana) vinha ocasionalmente para celebrar Missa e administrar os sacramentos. Mais tarde a Paróquia foi legada aos cuidados dos Padres Salesianos cujo Quartel General estava em Campo Grande e dos quais nós recebemos a Paróquia em 22 de Janeiro de 193022

A informação consta do relato dos Redentoristas quando receberam a Paróquia de Aquidauana dos Salesianos. Para o momento, o fundamental é destacar que "o povo de Deus estava praticamente como ovelhas sem pastor - mergulhado na miséria espiritual e contaminado pela superstição. 23 Dentre os membros do povo de Deus estavam os Terena. Não avalio que a situação estava ruim para os indígenas. Só constato que a capilaridade do Cristianismo ainda estava se processando.

${ }^{21}$ ESKER, Pe. Karl. Pequenas Histórias de Aquidauana. Arquivo da Igreja Católica de Aquidauana Nossa Senhora da Conceição (22/01/1930). Traduzido em 2001.

22 Idem, ibidem, p. 1.

${ }^{23}$ Apelo de Dom Carlos Luís D’Amour ao Padre Malan para que autorizasse a Missão Salesiana de 1898. 
Os Terena, contudo, no contexto do início do século XX, se autodenominam cristãos católicos. No entanto, ao passo que a Igreja Católica ia se institucionalizando nas recém-criadas Reservas Indígenas, as missões protestantes também se movimentavam rumo à catequização dos povos desses novos territórios.

A Inland South America Mission Union (ISAMU-1912) foi à primeira Missão a entrar na Reserva de Taunay/lpegue, através das lideranças da Aldeia Bananal, segundo os relatos escritos das lideranças religiosas Terena no Livro Atas da Missão União das Igrejas Evangélicas da América dos Sul, criada pelos indígenas e pelos missionários estrangeiros em 1972. Outra fonte que reconhece a ISAMU como a missão primogênita é o Livro escrito pelo Missionário Whittington ${ }^{24}$ que narra a experiência de sua família com os Terena na Reserva de Taunay/Ipegue e em outras reservas na região na primeira fase missionária.

A entrada na Reserva foi conflituosa, porém o trabalho desenvolvido superou essa situação histórica. Paralelamente às atividades educacionais, a Missão prestava assistência à saúde indígena. Enquanto o Sr. Whittington ensinava na escola, sua esposa desenvolvia atendimentos aos indígenas doentes, principalmente às crianças. $\bigcirc$ atendimento restringia-se aos poucos conhecimentos práticos dela enquanto enfermeira. Essas atividades proporcionavam relacionamentos diretos com as pessoas adultas, que eram visitadas pela enfermeira e com as crianças, que iam para a escola aprender a ler e escrever, bem como alguns adultos. ${ }^{25}$

As visitas domésticas eram consideradas pelo casal de missionários como oportunidades ímpares para a difusão do Evangelho. A pessoa que estava adoentada e, portanto, fragilizada, estava mais afeita a acreditar em um curandeiro superior a todos os demais. Em um dos trechos da narrativa o missionário Whittington destacou "... oportunidades de ouro para que pudéssemos falar para as pessoas sobre o maior Médico"26

A expressão "o maior médico" refere-se ao Deus cristão e faz contraponto ao médico feiticeiro dos Terena, o Koixomuneti. Evidencia que os missionários protestantes combatiam as lideranças religiosas do povo Terena e destaca uma relação marcada por conflitos religiosos entre os indígenas que se convertiam ao protestantismo e os que permaneciam católicos e seguidores dos xamãs. Os koixomuneti foram traduzidos pelos missionários da ISAMU como "médicosfeiticeiros", e, portanto, foram combatidos em nome do Grande Médico apresentado

\footnotetext{
24 WHITTINGTON, Rev. Harry. On the Indian Trail in Paraguay and Brazil:the struggles and triumphs encountered by a Missionary seeking Jewels. Edimburgh: Knox Press, s/d.

25 Idem, ibidem, p. 134.

${ }^{26}$ Idem.
}

\footnotetext{
MuUka. Noemia dos Santos Fereira \& OkTfZ, Kosalvo Ivarra. Tempo e memória no antiso Mato Grosso: a (re)siunificaça do cristianismo ocidental na cosmolosia Terena. albuquerque: revista de história. val. 9, no 18. jul.-dez. de 2017 . p. $33-47$.
} 
pelos missionários, que ocupava um plano superior aos "médicos-feiticeiros", segundo os missionários.

Os koixomuneti Terena foram inicialmente temidos, combatidos, excluídos ou convertidos pelos missionários. Alguns se aproximaram da Missão. Eram representados pelos missionários como a expressão do demônio, inimigo do "Grande Curador". Esses xamãs eram os perpetuadores da espiritualidade Terena. Dessa forma, os missionários procuravam meios para minar suas forças. Uma estratégia utilizada e eficaz, segundo seus próprios relatos, foi à persuasão, através da evangelização, dos membros da famílía nuclear do mais poderoso xamã de Bananal. Os missionários relataram minuciosamente essa vitória sobre o representante do Xamanismo.

Os médico-feiticeiros, segundo o relato do missionário Whittington, exerciam grande poder de controle sobre as aldeias. Em Bananal um xamã tentou desconstruir os trabalhos evangelizadores de acordo com os depoentes. Segundo ele, Deus teria sido muito sutil conduzindo sua esposa e filha para o protestantismo, isolando o poderoso xamã. Após a conversão ao Evangelho, ambas abandonaram suas antigas práticas. De acordo com a interpretação do missionário essa foi uma prova divina do poder do Evangelho contra as entidades espirituais daquele médicofeiticeiro.

missionário enfatizou em seu relato que um dos filhos do xamã lhes comunicara que o pai havia atentado contra a Missão. No entanto, o espírito enviado pelo koixomuneti à casa da Missão, com o objetivo de aprisionar e escravizar a todos que lá se encontravam, fora desviado de sua meta. Além de não ter conseguido entrar na casa da Missão, o espírito retornou ao emissário reenviado por um grupo de crentes em oração. Através do filho, seu porta-voz, o koixomuneti admitía aos missionários e à sua comunidade, que a força do Deus cristão era superior a sua. Retirava-se do embate contra os missionários. A partir da rendição, toda a sua família se convertera, menos o Koixomuneti. $\bigcirc$ filho mais novo tornou-se um líder religioso em Bananal. Geração após geração, descendentes daquele grande feiticeiro participaram da liderança indígena crente, difundindo o Evangelho

Em nossa análise, esse relato-testemunho tem no mínimo duas intenções. A primeira é provar aos indígenas que o Deus cristão é superior aos espíritos protetores dos mais poderosos koixomuneti. Por isso, nenhum crente terá mais que temer os espíritos dos ancestrais Terena. Vencendo o xamã, o status dos missionários muda perante a comunidade indígena. Consequentemente, aqueles indígenas que já vinham sendo evangelizados têm mais uma confirmação de que estão no caminho correto - a conversão ao Evangelho. A outra seria demonstrar que a força de combater $\circ \mathrm{mal}$ ou realizar $\circ$ bem, antes concentrados

\footnotetext{
MuUka. Noemia dos Santos Fereira \& OkTfZ, Kosalvo Ivarra. Tempo e memória no antiso Mato

Grosso: a (re)siunificaça do cristianismo ocidental na cosmolosia Terena.

albuquerque: revista de história. val. 9, no 18. jul.-dez. de 2017. p. $33-47$.
} 
exclusivamente no koixomuneti, estava se distribuindo entre os crentes através do poder da Palavra de Deus. A Igreja unida tinha o poder de combater os xamãs, representantes do Inimigo, e outros males, através da oração.

Aos poucos, a ação missionária protestante foi minando o poder do xamã através da ascensão e descentralização do poder da fé fundamentada na Bíblia - a poderosa palavra de Deus. A perseguição ao Xamanismo e sua materialização - os rituais - foi uma das atividades mais difundidas pelos missionários. A tática missionária foi contestar o Xamanismo afirmando sua negatividade através da associação com as forças demoníacas prejudiciais à convivialidade interna e externa. Xamã fora eleito o principal inimigo Terena do Cristianismo.

Todas as forças contrárias ao desenvolvimento dos serviços religiosos protestantes eram consideradas demoníacas e precisavam ser combatidas. De uma forma ou de outra, essas forças eram combatidas. $\bigcirc$ médico-feiticeiro, por sua vez, viu toda a sua família converter-se ao Evangelho. Cada vitória missionária era comemorada com cultos e depoimentos dos participantes. Os depoimentos indígenas estimulavam seus patrícios à conversão. A cada conquista sobre o "demônio", mais pessoas eram atraídas para o Evangelho, segundo os missionários. O exemplo de transformação experimentado por um Terena funcionava como um artifício de atração, tal como uma isca para um peixe.

À chegada da Missão protestante e dos primeiros Terena convertidos, realçou-se a latente identidade cristã católica indígena. Em contraponto aos Terenas evangélicos, constituem-se os Terenas católicos. ${ }^{2728}$ Apesar do curto tempo em contato com o catolicismo de missão, os Terena continuaram convivendo com experiências de catequese nas passagens dos religiosos pelas fazendas, nas quais muitos trabalharam após o desfecho da Guerra contra o Paraguai. A hipótese que defendi na dissertação e reiterei na tese, é que o realçamento da identidade católica foi uma tática dos Terena que discordavam da conversão do Grupo Terena, politicamente hegemônico, ao culto protestante. ${ }^{29}$

É evidente que o Cristianismo passou a ocupar um espaço sócio-político de destaque nas aldeias Terena dos Postos Indígenas de Ipegue e Bananal no início do século passado e, posteriormente, difundiu-se nas demais reservas. Contudo, os indícios demonstram que o Xamanismo continuou a desempenhar um papel

27 OLIVEIRA, Roberto Cardoso de. Do Índio ao Bugre: O Processo de Assimilação dos Terena. Rio de Janeiro: Francisco Alves, 1976.

${ }^{28}$ MOURA, N, S, P. O processo de terenização do cristianismo na terra indígena Taunay/lpegue no século XX. Tese (Doutorado em Ciências Sociais), Universidade Estadual de Campinas, Instituto de Filosofia e Ciências Humanas. Campinas, 2009.

29 Idem. 
central nas comunidades Terena. Tanto é verdade, que nos últimos anos o movimento indígena Terena tem se colocado diante da retomada de terras tradicionais e a principal liderança é o xamã, presente nas atividades mais significativas.

\section{alqumas considerações}

Segundo Carvalho, ${ }^{30}$ com quem concordamos, os Terena não substituíram a sua cosmovisão por outras doutrinas veiculadas pelas religiões cristãs. Podemos até dizer que essa vísão de mundo foì experimentando mudanças no processo secular de contato, mas não prioritariamente em decorrência de uma incorporação da visão de mundo veiculada pelo Cristianismo.

○ "realismo", o "pragmatismo", o "acaboclamento", o "abugramento", talvez sejam comportamentos e atitudes utilizados pelos Terena, diríamos que, principalmente pelas lideranças, para sinalizar à sociedade brasileira que os mesmos possuem as capacidades e habilidades para conviver em situações sociais diferentes das suas. Independentemente dessas, em suas aldeias, continua-se reproduzindo o seus modus vivendí. De acordo com a produção antropológica recente, embasada em laudos periciais ${ }^{31}$, essa etnia é caracterizada por um conjunto de elementos culturais que informam e orientam seus comportamentos, atitudes e posturas nas relações internas ou externas as suas aldeias e reservas. Com relação à esfera religiosa a matriz orientadora continua sendo o xamanismo Terena.

A estratégia utilizada foi ocupar os espaços políticos, territoriais e religiosos, que lhes foram concedidos pelo Império e depois pela República brasileira. Na virada do século XX, os Terena eram cristãos e colaboravam com o governo brasileiro na tarefa de civilizar outras etnias arredias. Identificar-se como cristão era uma estratégia contra a retaliação brasileira e uma forma de aproximação dos não índios. Entretanto, no contexto final do século XIX e primeiras décadas do XX, no sul da

\footnotetext{
${ }^{30}$ CARVALHO, Fernanda. Koixomuneti e outros curadores: xamanismo e práticas de cura entre os Terena. Dissertação (Mestrado em Antropologia), FLCH, Universidade de São Paulo. São Paulo, 1996, 143p.

${ }^{31}$ Acessamos os laudos periciais realizados por Azanha (AZANHA, Gilberto. As Terras Indígenas Terena no Mato Grosso do Sul. In: <www.trabalhoindigenista.org.br>. 2004.), Oliveira \& Pereira (PEREIRA, Levi Marques \& OLIVEIRA, J.E. Perícia Judicial apresentada ao Ministério da Justiça, 2003.). Na verdade, estes laudos constituem-se em fontes a ser trabalhadas pelos pesquisadores, embora sejam instrumentos jurídicos nos quais a justiça pauta-se para deliberar sobre uma questão específica - ampliação de terras indígenas. Esta questão de terras desencadeada pelo movimento indígena Terena, no caso em específico, é uma ação política pela qual essa etnia busca resgatar terras invadidas por fazendeiros ou legalizadas pelo Estado brasileiro pertencentes, segundo o entendimento indígena, a seus ancestrais.
} 
Província de Mato Grosso não era necessário o cristão ter o domínio das doutrinas da Igreja Católica.

processo de institucionalização do Catolicismo ainda era incipiente. Bastava se reconhecer enquanto tal. Tanto eram assim, que as formas de expressão da fé se davam muitas vezes, nos rituais dirigidos pelos capelães e em outras pelos próprios habitantes leigos.

Assumir-se cristão era uma condição para continuar sendo considerado amigo do poder. No entanto, não era somente os Terena que procuravam estreitar os laços de amizade com o Estado. A estratégia do Governo, desde o final da Guerra da Tríplice Aliança, era fortalecer suas fronteiras através do povoamento da região e para isso dependia das etnias indígenas. Naquele momento, era imprescindível para o Estado continuar tendo o apoio e a amizade dos índios mansos. A política de aliança entre o Governo e as etnias afeitas ao contato perdurará por toda a primeira metade do século XX.

Por outro lado, o protestantismo trazia consigo a educação e a saúde e isso era importante para as lideranças Terena no início do século XX. Contudo, os missionários combateram os xamãs e suas práticas ritualísticas. Por fim, ficaram o catolicismo, o protestantismo e o xamanismo como suportes religiosos entre os Terena. E cada grupo segue acionando a religiosidade que lhes atende em cada contexto. No momento atual, está em pauta a bandeira de retomada de terras tradicionais Terena. A religião tradicional está mais visível e o papel do xamã mais realçado. 